\title{
AUGUSTO ÓPẼ DA SILVA KAINGANG: PRESENTE!
}

ROBERTO ANTONIO LIEBGOTT ${ }^{1}$

CIMI SUL

Fazer memória para homenagear este grande líder é uma tarefa gratificante e ao mesmo tempo exigente, já que as palavras nem sempre expressam o sentido das experiências partilhadas. Em uma acepção ampla, recordar não é apenas refazer um caminho trilhado, é fazer o vivido passar pelo coração. Não há outro modo de falar de Augusto Ópẽ da Silva Kaingang senão inserindo esse falar, pensar e sentir na ordem do coração. Ele foi, como se afirma na nota de pesar pelo seu falecimento da Articulação dos Povos Indígenas do Sul do Brasil,

um guerreiro forte e sábio, foi nosso professor e exemplo a todos os militantes, principalmente da região sul. Suas palavras profundas, fortes, sempre nos impulsionaram a nos mantermos firmes na luta e incansáveis na defesa dos nossos direitos. Suas palavras ficarão para sempre gravadas em nossos corações.

Augusto Ópẽ, quando se manifestava publicamente sobre os direitos indígenas, denunciava a omissão, a negligência e a conivência dos governantes diante da realidade de sofrimento, angústia e morte dos povos indígenas. Falava com contundência contra os ataques aos direitos originários dos povos, especialmente às terras que tradicionalmente ocupam. Ele costumava dizer que os governantes de hoje não matam mais com armas de fogo ou envenenamento, mas com a caneta, pois fazem leis e decretos que prejudicam a população indígena e aniquilam suas condições de vida.

\footnotetext{
${ }^{1}$ CIMI Sul - Equipe de Porto Alegre. E-mail: cimisul-equipe-poa@uol.com.br .
} 
Dentre as muitas falas marcantes e profundas do líder Augusto Ópẽ, destaca-se uma, dirigida aos professores e alunos da Universidade Federal de Santa Maria, quando estes visitaram o acampamento kaingang:

A vida, não sei o que é vida para vocês, bom, cada nação, cada origem pensa diferente. Mas, para nós, quando se fala de vida estamos falando de cultura, a cultura viva, a língua viva. Apesar dos 513 anos, aqui no meio da cidade de Santa Maria, $100 \%$ das crianças falam a língua. Então, para mim, isso é motivo de emoção, mas também é motivo de história de resistência, porque a colonização cortou nossos galhos, cortou nossos troncos, mas esqueceu de arrancar nossas raízes que hoje brotam cada vez mais fortes ${ }^{2}$.

As palavras fortes, proferidas com uma expressão amorosa e singela, nos fazem vislumbrar não a face de um povo sem esperanças (apesar das injustiças, violências e privações vividas) e sim a face de um povo guerreiro, que luta, resiste, se mobiliza e acredita no futuro.

Augusto é reconhecido e respeitado por sua atuação estratégica nas comunidades e junto às lideranças de seu povo. Era um articulador, um conselheiro, um sábio que aglutinava forças de resistência contra as ações e setores anti-indígenas. Por mais de 30 anos foi porta-voz da esperança em toda a Região Sul. Em qualquer lugar onde havia uma demanda por terra, onde havia luta ou onde as comunidades kaingang, guarani, xokleng e xetá enfrentavam dificuldades, o Augusto se fazia presente. As terras indígenas, demarcadas ou em demarcação, na Região Sul do Brasil, têm um "pedacinho de vida do Augusto Ópẽ".

Externamente, junto a outros setores, organizações, movimentos sociais e populares, ele foi um articulador político, um construtor de alianças pela defesa da vida, da cidadania e dos direitos humanos. Onde ocorriam reuniões, seminários e conferências sobre as temáticas ambientais, indígenas, quilombolas, ou sobre os mais variados assuntos de interesse dos povos indígenas, lá estava o Augusto expondo suas ideias, propostas e reflexões.

\footnotetext{
2 Parte deste pronunciamento está disponível em https://www.youtube.com/watch?v=9bAOtuk_Ml0, acesso em 20 de outubro de 2014.
}

Espaço Ameríndio, Porto Alegre, v. 8, n. 2, p. 369-373, jul./dez. 2014. 
Ele sempre reafirmava que a causa indígena está entrelaçada a outras causas sociais - dos quilombolas, dos sem-terra, dos sem-teto, dos desempregados - e compõe pautas comuns de reivindicação pela garantia da terra e sua função social, bem como pelo estabelecimento de condições para que todos possam ter uma vida digna. Mesmo estando já bastante doente, Augusto participou de uma reunião em Porto Alegre, no Ministério Público Federal, para discutir as demarcações de terras e a situação dos pequenos agricultores afetados pelas demarcações. $\mathrm{Na}$ oportunidade, estavam presentes autoridades dos governos federal e estadual que pretendiam convencer as lideranças indígenas a abrirem mão do direito à demarcação de terras tradicionais em troca de áreas a serem adquiridas pelo Estado do Rio Grande do Sul. Augusto Ópẽ tomou a palavra e enfaticamente se posicionou:

Nós não temos nada contra os agricultores, nós defendemos seus direitos, reconhecemos que estão sofrendo, mas não somos os culpados pelo fato dos governos, no passado, terem vendido as nossas terras. Vamos lutar para que os governos indenizem os agricultores de forma justa, mas nós não vamos negociar os nossos direitos. Direito não se negocia e os nossos estão bem escritos na Constituição Federal. Direito se cumpre ${ }^{3}$.

Nesta mesma reunião, Augusto Ópẽ falou sobre os direitos indígenas e a necessidade de haver uma ampla articulação entre os quilombolas, os movimentos sociais para enfrentar as políticas que excluem e marginalizam as pessoas:

Nós precisamos firmar nossas alianças com aqueles que sofrem injustiças e pressionar o governo para que cumpra com suas obrigações. O governo é que nem feijão velho, destes que distribuem nas cestas básicas, só cozinha na base da pressão. O governo só vai agir mediante muita pressão ${ }^{4}$.

Augusto Ópẽ faleceu no dia 30 de maio de 2014. Ele lutou durante anos contra um câncer. Enfrentou a doença como enfrentava

\footnotetext{
${ }^{3}$ Anotações pessoais feitas durante a reunião realizada no Ministério Público Federal de Porto Alegre, em 4 de setembro de 2013.

${ }^{4}$ Idem.
}

Espaço Ameríndio, Porto Alegre, v. 8, n. 2, p. 369-373, jul./dez. 2014. 
todas as lutas que travou na vida. Determinado, corajoso e esperançoso. Recebi um telefonema do Augusto alguns dias antes de seu falecimento e, na oportunidade, ele disse estar se sentindo bem melhor com o tratamento que desenvolvia e se colocou à disposição para participar de um encontro de lideranças kaingang para definir as estratégias do movimento indígena diante das proposições do governo federal em realizar as "mesas de diálogo" sobre as demarcações de terras e os conflitos com agricultores. Ele estava bastante preocupado com a conjuntura política e o desencadeamento de uma campanha de criminalização das lideranças indígenas e de outros setores da sociedade que se mobilizam pela garantia de seus direitos. Ele reafirmou que os povos indígenas precisam manter a união e a articulação com outros movimentos, e não permitir que os direitos conquistados com luta e sangue sejam ignorados em função de interesses econômicos e políticos.

Augusto Ópẽ sempre nos surpreendia com palavras de encorajamento e de esperança, tal com as que proferiu na ocasião da visita de docentes e discentes da universidade de Santa Maria, anteriormente referida:

Nós temos um sonho de ver um mundo melhor, um mundo que não tenha criminalidade, um mundo que não tenha preconceito, um mundo que não tenha discriminação. Este sonho é possível quando nós nos unirmos, com o respeito a cada um de nós, cada um de nós fazendo a sua parte, aí outro mundo é possível! ${ }^{5}$.

O último acontecimento marcante e surpreendente ocorreu depois de sua morte, no momento em que seu corpo estava sendo velado dentro de uma pequena igreja evangélica, lá na aldeia em Iraí. Enquanto caciques kaingang rezavam e prestavam suas homenagens ao líder Augusto, centenas de pessoas, emocionadas, choravam. Sandro, um dos filhos do Augusto, estava sentado próximo ao caixão e chorava muito, enquanto outras pessoas tentavam consolá-lo. Eu estava de frente para o caixão e dirigi meu olhar para uma janela lateral entreaberta e percebi que um gafanhoto verde e grande pousou sobre as grades daquela

\footnotetext{
${ }^{5}$ Disponível em https://www.youtube.com/watch?v=9bAOtuk_M10, acesso em 20 de outubro de 2014.
} 
janela. Olhei e pensei: o que faz um gafanhoto no meio de tantas pessoas? O mais surpreendente é que o pequeno inseto sobrevoou a multidão e pousou no ombro esquerdo do Sandro e ali permaneceu por alguns segundos como que a consolá-lo. Depois pousou sob o caixão e ali permaneceu por muito tempo, observando o que se passava.

Ao me retirar da igrejinha, ainda impactado com o acontecimento, encontrei Valdomiro Vergueiro, cacique kaingang do Morro do Osso que estava bastante emocionado com as homenagens e sentimento de dor pela perda do amigo querido. Contei que havia visto, lá no meio da multidão, um gafanhoto pousar no ombro do Sandro e depois ao lado do caixão. Ele, com os olhos cheios de lágrimas e com sorriso nos lábios, afirmou que os Kaingang recebem, além do nome que vai na certidão de nascimento, um nome em kaingang, que é dado pelo kujá pajé - e que geralmente está relacionado à natureza. $\mathrm{O}$ nome dado ao Augusto foi Ópẽ, palavra que, na língua kaingang, significa Gafanhoto.

Porto Alegre, 23 de outubro de 2014. 